University of Nebraska - Lincoln

DigitalCommons@University of Nebraska - Lincoln

Faculty Papers and Publications in Animal

Science

Animal Science Department

June 2004

Responses to 19 generations of litter size selection in the NE

Index line. II. Growth and carcass responses estimated in pure

line and crossbred litters

D. B. Petry

University of Nebraska-Lincoln

J. W. Holl

University of Nebraska-Lincoln

R. K. Johnson

University of Nebraska-Lincoln, rjohnson5@unl.edu

Follow this and additional works at: https://digitalcommons.unl.edu/animalscifacpub

Part of the Animal Sciences Commons

Petry, D. B.; Holl, J. W.; and Johnson, R. K., "Responses to 19 generations of litter size selection in the NE Index line. II. Growth and carcass responses estimated in pure line and crossbred litters" (2004). Faculty Papers and Publications in Animal Science. 65.

https://digitalcommons.unl.edu/animalscifacpub/65

This Article is brought to you for free and open access by the Animal Science Department at DigitalCommons@University of Nebraska - Lincoln. It has been accepted for inclusion in Faculty Papers and Publications in Animal Science by an authorized administrator of DigitalCommons@University of Nebraska - Lincoln. 


\title{
Responses to 19 generations of litter size selection in the NE Index line. II. Growth and carcass responses estimated in pure line and crossbred litters ${ }^{1}$
}

\author{
D. B. Petry, J. W. Holl, and R. K. Johnson ${ }^{2}$ \\ Department of Animal Science, University of Nebraska, Lincoln 68583-0908
}

\begin{abstract}
Our objective was to estimate responses in growth and carcass traits in the NE Index line (I) that was selected for 19 generations for increased litter size. Differences between Line I and the randomly selected control line $(\mathrm{C})$ were estimated in pure line litters and in $\mathrm{F}_{1}$ and three-way cross litters produced by mating I and $\mathrm{C}$ females with males of unrelated lines. Contrasts of means were used to estimate the genetic difference between I and $\mathrm{C}$ and interactions of line differences with mating type. In Exp 1, 694 gilts that were retained for breeding, including $538 \mathrm{I}$ and $\mathrm{C}$ and $156 \mathrm{~F}_{1}$ gilts from I and C dams mated with Danbred NA Landrace (L) sires, were evaluated. Direct genetic effects of I and $\mathrm{C}$ did not differ for backfat (BF) at $88.2 \mathrm{~kg}$ or days to $88.2 \mathrm{~kg}$; however, I pigs had $1.58 \mathrm{~cm}^{2}$ smaller LM area than did $\mathrm{C}$ pigs $(P<0.05)$. Averaged over crosses, $\mathrm{F}_{1}$ gilts had $0.34 \mathrm{~cm}$ less $\mathrm{BF}, 4.29 \mathrm{~cm}^{2}$ greater LM area, and $31 \mathrm{~d}$ less to $88.2 \mathrm{~kg}$ than did pure line gilts $(P<$ 0.05). In Exp 2, barrows and gilts were individually penned for feed intake recording from 27 to $113 \mathrm{~kg}$ and slaughtered. A total of $43 \mathrm{I}$ and $\mathrm{C}$ pigs, $77 \mathrm{~F}_{1}$ pigs produced from pure line females mated with either $\mathrm{L}$ or Danbred NA 3/4 Duroc, 1/4 Hampshire boars (T), and
\end{abstract}

76 three-way cross pigs produced from $\mathrm{F}_{1}$ females mated with $\mathrm{T}$ boars were used. Direct genetic effects of I and C did not differ for ADFI, ADG, G:F, days to 113 $\mathrm{kg}, \mathrm{BF}, \mathrm{LM}$ area, ultimate $\mathrm{pH}$ of the LM, LM Minolta $\mathrm{L}^{*}$ score, or percentage of carcass lean. Interactions of line effects with crossing system were significant only for days to $113 \mathrm{~kg}$. Pure line I pigs took $4.58 \pm 4.00 \mathrm{~d}$ more to reach $113 \mathrm{~kg}$ than did $\mathrm{C}$ pigs, whereas I cross $\mathrm{F}_{1}$ pigs reached $113 \mathrm{~kg}$ in $6.70 \pm 3.95 \mathrm{~d}$ less than $\mathrm{C}$ cross $\mathrm{F}_{1}$ pigs. Three-way cross and $\mathrm{F}_{1}$ pigs did not differ significantly for most traits, but the average crossbred pig consumed more feed $(0.23 \pm 0.04 \mathrm{~kg} / \mathrm{d})$, gained more BW per unit of feed consumed $(0.052 \pm 0.005 \mathrm{~kg} / \mathrm{kg})$, grew faster $(0.20 \pm 0.016 \mathrm{~kg} / \mathrm{d})$, had less BF $(-0.89 \pm$ $0.089 \mathrm{~cm})$, greater LM area $\left(5.74 \pm 0.926 \mathrm{~cm}^{2}\right)$, more lean $(6.21 \pm 0.90 \%)$, and higher $L^{*}$ score $(5.27 \pm 1.377)$ than the average pure line pig did $(P<0.05)$. Nineteen generations of selection for increased litter size produced few correlated responses in growth and carcass traits, indicating these traits are largely genetically independent of litter size, ovulation rate, and embryonic survival.

Key Words: Carcass, Crossbreeding, Growth, Litter Size, Pigs, Selection

(C2004 American Society of Animal Science. All rights reserved.

J. Anim. Sci. 2004. 82:1895-1902

\section{Introduction}

Terminal crossing systems with specialized sire and dam lines is commonplace today. Maternal line selection is often on an index of EBV of litter size, growth, and carcass traits estimated assuming that litter size is genetically independent of growth and carcass traits. Low to moderate correlations of litter size with backfat thickness and growth rate were reported by Young et

\footnotetext{
${ }^{1}$ Published as paper No. 14307, Journal Ser., Nebraska Agric. Res. Div., Univ. of Nebraska, Lincoln 68583-0908.

${ }^{2}$ Correspondence: A218 Animal Sciences (phone: 402-472-6404; fax: 402-472-6362; e-mail: rjohnson5@unl.edu).

Received October 17, 2003.

Accepted March 25, 2004.
}

al. (1977), and correlated responses in litter size from lean growth selection (Cleveland et al., 1988) or selection for components of growth that did not decrease feed intake (Kerr and Cameron, 1995) were not significant.

In the future, emphasis on litter size may increase in some maternal lines to produce highly prolific females. Correlated responses predicted from covariance analyses or estimated from selection for growth may not apply in these highly prolific lines. Only a few estimates of correlated responses in growth and carcass traits from relatively short-term selection experiments for litter size exist. Ruíz-Flores and Johnson (2001) estimated correlated responses after eight generations of twostage selection for ovulation rate and litter size; Estany et al. (2002a,b) and Holl and Robison (2003) estimated responses after one and nine generations of selection for 
litter size, respectively. Responses in these experiments were inconsistent, but they indicated possible positive genetic correlations of growth and backfat with litter size. These estimates were made in pure line pigs. It is equally important to estimate responses in crossbred pigs.

An experiment was conducted in which 19 generations of selection for ovulation rate, embryonic survival, and litter size were practiced. The purpose of this study was to estimate correlated responses in growth and carcass traits in pure line and crossbred pigs to this selection and to estimate the improvements from crossing a highly prolific line selected only for litter size with improved industry lines.

\section{Materials and Methods}

\section{Population}

The population was a composite of Large White and Landrace (L) produced by reciprocally crossing boars and sows of the two breeds in 1979. Random selection and mating of the $\mathrm{F}_{1}$ and $\mathrm{F}_{2}$ generations were used to produce $\mathrm{F}_{3}$ litters. Pigs within these litters, born in 1981 and designated Generation 0, were randomly assigned to the Control line (C) that was randomly selected or the Index line (I) that was selected for an index of ovulation rate and embryonic survival for 11 generations and then for increased litter size through Generation 19. Details of the selection experiment and responses through Generation 14 are in Johnson et al. (1999).

Pigs from Generations 17, 18, and 19 were used in the experiment reported herein. Eight genetic groups, including pure line I and $\mathrm{C}$ pigs, crosses of I and $\mathrm{C}$ females with L or $3 / 4$ Duroc $\times 1 / 4$ Hampshire terminal sires (T) supplied by Danbred NA (Seward, NE), and three way crosses of $\mathrm{L} \times \mathrm{I}$ and $\mathrm{L} \times \mathrm{C} \mathrm{F}_{1}$ females mated with $\mathrm{T}$ boars, were produced. Genetic types included I $\times \mathrm{I}$ and $\mathrm{C} \times \mathrm{C}$ pure line pigs; $\mathrm{L} \times \mathrm{I}, \mathrm{L} \times \mathrm{C}, \mathrm{T} \times \mathrm{I}$, and $\mathrm{T}$ $\times \mathrm{C} \mathrm{F}_{1}$ pigs; and $\mathrm{T}(\mathrm{L} \times \mathrm{I})$, and $\mathrm{T}(\mathrm{L} \times \mathrm{C})$ three-way cross pigs. Further details of the mating design and reproductive responses in the females are given in Petry and Johnson (2004).

\section{Data Collection}

A total of 694 gilts from Generations 17, 18, and 19 (1998, 1999, and 2000) retained for breeding, including 538 pure line gilts and $156 \mathrm{~F}_{1}$ gilts, was evaluated. Pure line gilts were identified as replacements based on the dam's litter size; $\mathrm{F}_{1}$ gilts were selected randomly within litter to represent all available litters. Gilts were developed in a nursery to an age of approximately $56 \mathrm{~d}$, at which point they were moved to a naturally ventilated grow-finish house with 10 pigs per pen $\left(0.74 \mathrm{~m}^{2} / \mathrm{pig}\right)$. They were given ad libitum access throughout the growing period to a standard corn-soybean meal diet containing (as fed) $16 \% \mathrm{CP}, 0.81 \%$ lysine, $0.65 \% \mathrm{Ca}$, and
Table 1. Number of group-fed gilts of each group measured per year/generation

\begin{tabular}{lrrcc}
\hline \hline & \multicolumn{4}{c}{ Genetic group $^{\mathrm{a}}$} \\
\cline { 2 - 5 } Year/generation & $\mathrm{C}$ & $\mathrm{I}$ & $\mathrm{L} \times \mathrm{C}$ & $\mathrm{L} \times \mathrm{I}$ \\
\hline $1998 / 17$ & 124 & 119 & - & - \\
$1999 / 18$ & 70 & 100 & 39 & 40 \\
$2000 / 19$ & 68 & 57 & 39 & 38 \\
\hline
\end{tabular}

${ }^{\mathrm{a}} \mathrm{C}=$ Control; $\mathrm{I}=$ Index $; \mathrm{L}=$ Danbred NA Landrace sire.

$0.55 \% \mathrm{P}$. When gilts averaged $88.2 \mathrm{~kg}$, backfat (BF) and LM area were recorded with an Aloka 500V realtime ultrasound instrument equipped with a $3.5-\mathrm{MHz}$, 17-cm linear transducer (Corometrics Medical System, Inc., Wallingford, CT), with the probe placed approximately at the 10th rib, $6.4 \mathrm{~cm}$ off the midline and perpendicular to the skin surface. Days to mean final weight of all gilts in the group ( $88.2 \mathrm{~kg}$ ) was calculated for each gilt from final age and weight according to procedures described in the Guidelines for Uniform Swine Improvement (NSIF, 1991). Longissimus muscle area was not measured in 1998. Table 1 contains the number of gilts of each genetic makeup in each season.

The sows that produced the 1999 litters were mated after their first litter to produce parity 2 litters as described in Petry and Johnson (2004). After replacement boars and gilts had been selected, 196 barrows and gilts from the 1999 litters and from the first parity of the 2000 litters were randomly selected when they were in the nursery and moved at $65 \mathrm{~d}$ of age to a facility in which they were penned individually $\left(1.86 \mathrm{~m}^{2} / \mathrm{pig}\right)$ for feed intake recording. Pigs produced in 2000 by parity 1 sows in 1999 were born in summer (designated as Season 1), whereas those produced by parity 2 sows in 1999 were born in the winter (designated as Season 2). Table 2 shows the number of barrows and gilts of each genetic makeup in each season.

Pigs were given $1 \mathrm{wk}$ to adjust to the facility and then weighed. They were given ad libitum access to the same diet described above for the replacement gilts. Mechanical ventilation and heating was used to maintain the temperature between 18.3 and $26.7^{\circ} \mathrm{C}$, depending on season.

Data for the pigs fed individually were collected on consecutive 3 -wk intervals from the time they were placed on test at d 72 (mean weight $=27.2 \mathrm{~kg}$ ) until they were removed from test at approximately $113 \mathrm{~kg}$. Pigs were weighed, feed intake was recorded, and BF and LM area were recorded at the end of each interval; ADFI (as fed), ADG, and G:F were calculated for each pig at each interval and for the entire test period. Days to $113 \mathrm{~kg}$ for each pig was calculated from final weight and age. After final weight, BF, and LM area were recorded, pigs were transported to Sioux Preme (Sioux Center, IA) for processing and evaluation. Percentage of carcass lean (LEAN\%) estimated by total body electrical conductivity (EM-Scan/TOBEC, Springfield, IL), 
Table 2. Number of individually fed barrows and gilts of each group measured per season

\begin{tabular}{lcccccccc}
\hline \hline & \multicolumn{7}{c}{ Genetic group of pig } \\
\cline { 2 - 8 } Year/season $^{\mathrm{a}}$ & $\mathrm{C}$ & $\mathrm{I}$ & $\mathrm{L} \times \mathrm{C}$ & $\mathrm{L} \times \mathrm{I}$ & $\mathrm{T} \times \mathrm{I}$ & $\mathrm{T} \times \mathrm{C}$ & $\mathrm{T}(\mathrm{L} \times \mathrm{C})$ & $\mathrm{T}(\mathrm{L} \times \mathrm{I})$ \\
\hline $1999 / 1$ & 11 & 11 & 11 & 11 & & & 10 & 11 \\
$1999 / 2$ & 11 & 10 & 11 & 11 & & 16 & 16 & 17 \\
$2000 / 1$ & & & & & 11 & 11 \\
\hline
\end{tabular}

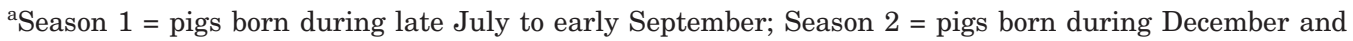
January.

${ }^{\mathrm{b}} \mathrm{C}=$ Control; $\mathrm{I}=$ Index; $\mathrm{L}=$ Danbred NA Landrace sire; $\mathrm{T}=$ Danbred NA Duroc-Hampshire terminal sire.

ultimate LM pH $24 \mathrm{~h}$ after slaughter, and Minolta $\mathrm{L}^{*}$ color score of the LM were recorded by technicians at Sioux Preme.

\section{Statistical Analyses}

Data for group-fed gilts and barrows and gilts fed individually were analyzed separately. The SAS software (SAS Inst., Inc., Cary, NC) was used for all analyses.

Backfat and LM area of group-fed gilts were fitted with PROC GLM to a model including the fixed effect of line within year/season subclass and weight of gilt as a covariate. Backfat and LM area were adjusted to a mean weight of $88.2 \mathrm{~kg}$. Days to $88.2 \mathrm{~kg}$ was fitted to the same model without weight as a covariate. Because all genetic groups were not produced in each year (Table 1), contrasts of least squares means within year, as illustrated in Table 3, were used to estimate genetic effects. The effects of interest were responses to selection in Line I estimated as differences between pigs containing I and $\mathrm{C}$ genes, interactions of selection responses when expressed in pure line or crossbred pigs, and responses due to crossbreeding estimated as differences in crossbred and pure line pigs.
The contrasts were applied in the following order: 1) First, the overall difference in direct effects between Lines I and $\mathrm{C}$ was estimated with coefficients that estimated $100 \%$ of the genetic difference $(-1$ and +1 on pure lines, -2 and +2 on $\mathrm{F}_{1}$, and the divisor of five because there are five pairs of means contrasted). 2) An interaction contrast was used to determine whether responses differed in pure line and $\mathrm{F}_{1}$ gilts. If an interaction existed $(P<0.05)$, response in each of the two groups was estimated, also with coefficients and divisor that resulted in an estimate of $100 \%$ of the difference between lines. 3) The average difference between I and $\mathrm{C} \mathrm{F}_{1}$ cross gilts and $\mathrm{I}$ and $\mathrm{C}$ pure line gilts was estimated.

The differences among lines in patterns of feed intake, growth, BF deposition, and LM area growth of pigs fed individually were similar across 3 -wk intervals (data not shown). Therefore, only overall performance is presented herein. The model included the fixed effect of line within year/season subclass, sex, line within year/season subclass by sex, and final live weight as a covariate (weight was omitted from the model for days to $113 \mathrm{~kg}$ ). The combined effect of season/genetic group was fitted together because all genetic groups did not occur in each season. Because of the confounding, linear

Table 3. Coefficients of contrasts among least squares means for each year/genetic subclass for group-fed gilts

\begin{tabular}{|c|c|c|c|c|c|c|}
\hline Year & Group $^{a}$ & $I-C^{b}$ & $\mathrm{R}: \mathrm{P}-\mathrm{F} 1^{\mathrm{c}}$ & $(\mathrm{I}-\mathrm{C})_{\mathrm{P}}{ }^{\mathrm{d}}$ & $(\mathrm{I}-\mathrm{C})_{\mathrm{F} 1}^{\mathrm{e}}$ & $F_{1}-P^{f}$ \\
\hline 1998 & C & -1 & & -1 & & \\
\hline 1998 & I & 1 & & 1 & & \\
\hline 1999 & $\mathrm{C}$ & -1 & -1 & -1 & & -1 \\
\hline 1999 & I & 1 & 1 & 1 & & -1 \\
\hline 1999 & $\mathrm{~L} \times \mathrm{C}$ & -2 & 2 & & -1 & 1 \\
\hline 1999 & $\mathrm{~L} \times \mathrm{I}$ & 2 & -2 & & 1 & 1 \\
\hline 2000 & C & -1 & -1 & -1 & & -1 \\
\hline 2000 & I & 1 & 1 & 1 & & -1 \\
\hline 2000 & $\mathrm{~L} \times \mathrm{C}$ & -2 & 2 & & -1 & 1 \\
\hline 2000 & $\mathrm{~L} \times \mathrm{I}$ & 2 & -2 & & 1 & 1 \\
\hline Divisor & & 5 & 2 & 3 & 2 & 4 \\
\hline
\end{tabular}

${ }^{\mathrm{a}} \mathrm{C}$ = Control; I = Index; L = Danbred NA Landrace sire; $\mathrm{T}$ = Danbred NA Duroc-Hampshire terminal sire.

${ }^{\mathrm{b}} \mathrm{I}-\mathrm{C}=$ average overall difference in direct effect between Line I and $\mathrm{C}$.

${ }^{\mathrm{c}} \mathrm{R}$ : $\mathrm{P}-\mathrm{F} 1$ tests the interaction of selection response $(\mathrm{I}-\mathrm{C})$ in $\mathrm{F}_{1}$ gilts vs. pure line gilts.

$\mathrm{d}(\mathrm{I}-\mathrm{C})_{\mathrm{p}}=$ difference in direct effect between $\mathrm{I}$ and $\mathrm{C}$ when measured in pure line gilts.

${ }^{e}(\mathrm{I}-\mathrm{C})_{\mathrm{F} 1}=$ difference in direct effect $(\mathrm{I}-\mathrm{C})$ when measured in $\mathrm{F}_{1}$ gilts.

${ }^{\mathrm{f}} \mathrm{F}_{1}-\mathrm{P}=$ average difference between $\mathrm{F}_{1}$ and pure line gilts. 
contrasts of least squares means within season, as illustrated in Table 4, were calculated to estimate genetic effects of interest. Contrasts were constructed to estimate responses to selection in Line I, interactions of selection responses when expressed in pure line or crossbred pigs, and responses due to crossbreeding. First, the overall difference between Lines I and $\mathrm{C}$ was estimated with coefficients of means $(+1$ or -1 on pure line means, +2 or -2 on $\mathrm{F}_{1}$ means, and +4 or -4 on three-breed cross means) and divisor (eight pairs of means were contrasted) that resulted in an estimate of $100 \%$ of the genetic difference between lines. Then, four interaction contrasts were calculated to determine whether the response differed in 1) pure line pigs and $\mathrm{F}_{1}$ crosses of $\mathrm{L}$ by $\mathrm{I}$ and $\mathrm{C}\left(\mathbf{F} \mathbf{1}_{\mathbf{L}}\right) ; 2$ ) pure line pigs and three-way cross pigs; 3) $\mathrm{F} 1_{\mathrm{L}}$ pigs and three-way cross pigs; or 4) $\mathrm{F}_{1}$ crosses of $\mathrm{T}$ with $\mathrm{I}$ and $\mathrm{C}\left(\mathrm{F} 1_{\mathrm{T}}\right)$ and threeway crosses. If interactions existed $(P<0.05)$, responses in each of the four groups were calculated, again with coefficients and divisor that resulted in an estimate of $100 \%$ of the difference between lines. Additional contrasts were used to estimate the difference between I and $\mathrm{C} \mathrm{F1} 1_{\mathrm{L}}$ pigs and $\mathrm{I}$ and $\mathrm{C}$ pure line pigs, the difference between $\mathrm{I}$ and $\mathrm{C}$ three-way cross pigs and $\mathrm{I}$ and $\mathrm{C} F 1_{\mathrm{L}}$ pigs, and the difference between $\mathrm{I}$ and $\mathrm{C}$ three-way cross pigs and $\mathrm{I}$ and $\mathrm{C} \mathrm{F} 1_{\mathrm{T}}$ pigs.

\section{Results}

\section{Growth of Group-Fed Gilts}

Table 5 shows contrasts among means for growth traits of the gilts retained for breeding. Differences between $\mathrm{I}$ and $\mathrm{C}$ in $\mathrm{BF}$ and days to $88.2 \mathrm{~kg}$ were not significant; I and C differed significantly in direct genetic effects on LM area. The correlated response to selection for increased litter size was $-1.58 \pm 0.61(P<$ $0.05) \mathrm{cm}^{2}$ smaller LM area in I gilts.

Interactions of the genetic difference between lines with genetic group were detected for BF and LM area. The differences between I and $\mathrm{C}$ estimated in pure line gilts were $-0.12 \pm 0.03 \mathrm{~cm}$ of $\mathrm{BF}$ and $-0.21 \pm 0.43 \mathrm{~cm}^{2}$ of LM area, whereas the difference estimated in $\mathrm{F}_{1}$ gilts was $0.08 \pm 0.05 \mathrm{~cm}$ more $\mathrm{BF}$ and $1.48 \pm 0.57 \mathrm{~cm}^{2}$ greater LM area. Averaged across lines, $\mathrm{F}_{1}$ gilts were younger at $88.2 \mathrm{~kg}(-31.19 \pm 2.45 \mathrm{~d})$ and had less BF $(-0.34 \pm$ $0.04 \mathrm{~cm})$ and greater LM area $\left(4.29 \pm 0.47 \mathrm{~cm}^{2}\right)$ than pure line gilts.

\section{Growth of Individually Fed Pigs}

Sex was significant for ADFI, ADG, and days to 113 $\mathrm{kg}$, and season/parity/line was significant for ADFI, $\mathrm{ADG}, \mathrm{G}: \mathrm{F}$, and days to $113 \mathrm{~kg}$. Interactions between these effects were not significant for any trait.

Estimates of contrasts among means are shown in Table 6. Direct effects of I and C did not differ $(P>0.05)$ for any trait, and an interaction between line difference and genetic group occurred only for days to $113 \mathrm{~kg}$. The difference between I and $\mathrm{C}$ estimated in pure line pigs was $4.58 \pm 4.00 \mathrm{~d}$, whereas the difference in $\mathrm{F} 1_{\mathrm{L}}$ crosses was $-6.70 \pm 3.95 \mathrm{~d}$.

The $\mathrm{F}_{1}$ Landrace pigs had significantly improved performance over pure line pigs. They consumed more feed per day $(0.26 \pm 0.05 \mathrm{~kg})$, gained weight more rapidly $(0.19 \pm 0.02 \mathrm{~kg} / \mathrm{d})$, reached $113 \mathrm{~kg}$ sooner $(27.65 \pm 2.81$ $\mathrm{d})$, and were more efficient $(0.045 \pm 0.006 \mathrm{~kg} / \mathrm{kg})$. The $\mathrm{F} 1_{\mathrm{T}}$ and $\mathrm{F} 1_{\mathrm{L}}$ cross pigs differed significantly only in efficiency of growth. The terminal $\mathrm{F}_{1}$ cross pigs gained $0.013 \pm 0.006 \mathrm{~kg}$ more weight per kilogram of feed consumed. Further improvements in performance occurred in three-way cross pigs, although none of the differences were significant.

\section{Carcass Traits}

The effect of sex was significant for BF and LEAN\%, and season/parity/line was significant for BF, LM area, LEAN\%, and Minolta $\mathrm{L}^{*}$ color score. The interaction between these effects was not significant for any trait.

Estimates of contrasts among means are given in Table 7. Average genetic effects of Lines I and $\mathrm{C}$ did not differ $(P>0.05)$ for any trait, and no contrast of interactions of line difference with genetic group was significant.

Averaged across Lines $\mathrm{I}$ and $\mathrm{C}$, Landrace cross $\mathrm{F}_{1}$ pigs had less BF $(-0.82 \pm 0.10 \mathrm{~cm})$, larger LM area $(5.22$ $\left.\pm 0.99 \mathrm{~cm}^{2}\right)$, more carcass lean $(5.52 \pm 0.96 \%)$, and more pale muscle as indicated by higher Minolta $\mathrm{L}^{*}$ score $(4.54 \pm 1.49)$ than pure line pigs. The $\mathrm{T}$ cross $\mathrm{F}_{1}$ and $\mathrm{L}$ cross $\mathrm{F}_{1}$ pigs did not differ significantly for any trait. Three-way cross pigs had significantly greater LM area than $\mathrm{F}_{1}$ pigs, but did not differ significantly from them for any other trait.

\section{Discussion}

Our first aim was to estimate correlated responses in growth and carcass traits in the I line. The longterm selection applied in it makes it a unique swine population for estimation of correlated responses. With the exception of a relatively small amount of withinlitter selection for birth weight in Generations 16 through 19 (see Petry and Johnson, 2004, for a description of this selection), Line I was selected exclusively for reproductive traits. Selection through Generation 11 was for an index of increased ovulation rate and embryonic survival. Subsequent selection through Generation 19 was for increased litter size at birth. Responses were estimated to be 6.62 ova at Generation 11 and 2.83 total pigs and 1.82 live pigs per litter at Generation 14 (Johnson et al., 1999). Averaged over Generations 17, 18, and 19, responses in litter size were estimated to be $3.53 \pm 0.30$ total pigs, and $2.53 \pm 0.30$ live pigs per litter (Petry and Johnson, 2004). As a percentage of the base generation mean, these changes range from approximately $25 \%$ for number of live pigs per litter to $47 \%$ for ovulation rate. 
Responses to litter size selection in pigs

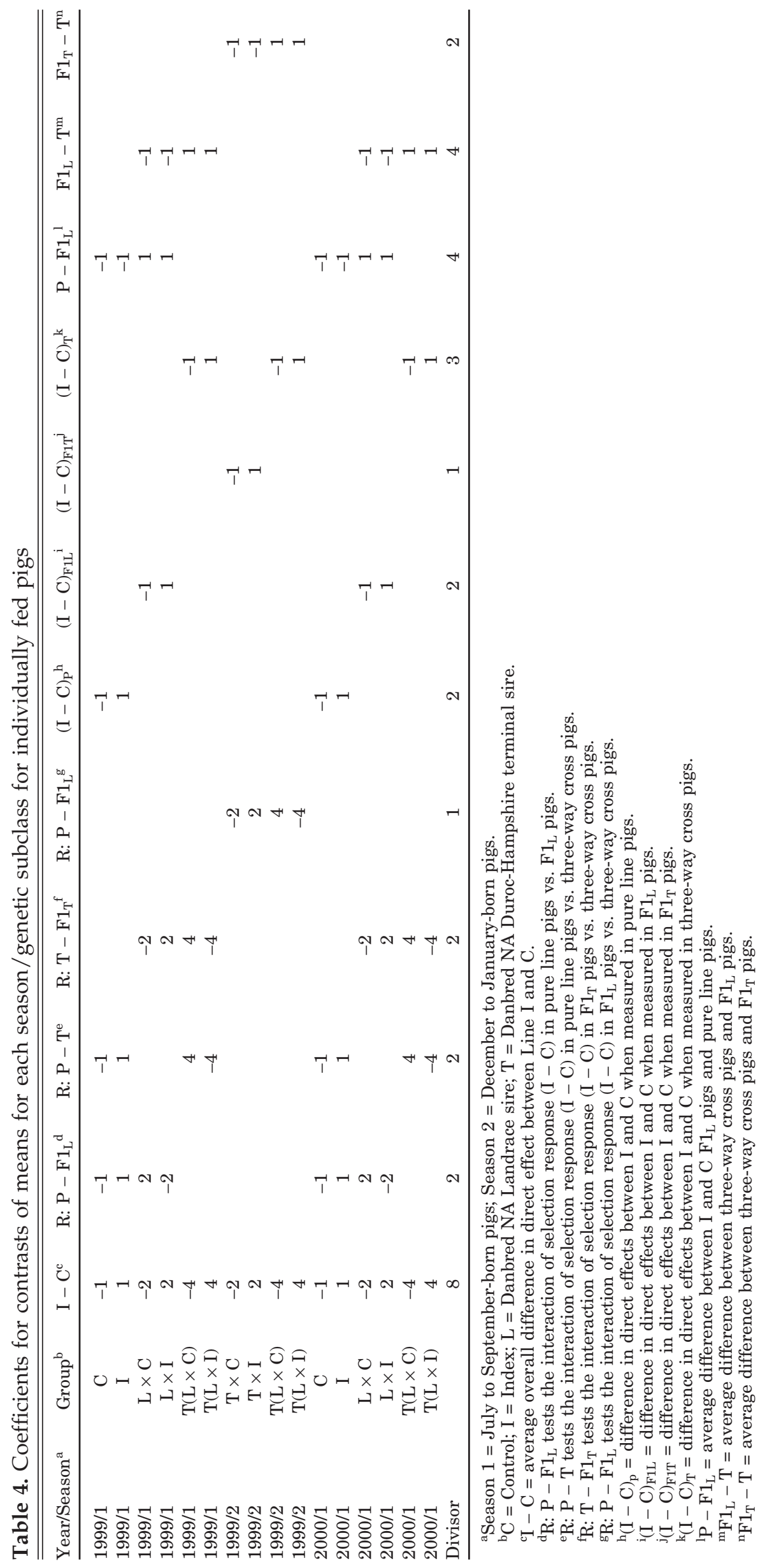


Table 5. Contrasts among means for traits of group-fed gilts

\begin{tabular}{|c|c|c|c|c|c|c|}
\hline \multirow[b]{2}{*}{ Contrast $^{\mathrm{a}}$} & \multicolumn{2}{|c|}{$\mathrm{BF}, \mathrm{cm}^{\mathrm{b}}$} & \multicolumn{2}{|c|}{$\mathrm{LM}$ area, $\mathrm{cm}^{2 \mathrm{c}}$} & \multicolumn{2}{|c|}{ Days to $88.2 \mathrm{~kg}$} \\
\hline & $\hat{\mathrm{u}}$ & $\mathrm{SE}$ & $\hat{\mathrm{u}}$ & $\mathrm{SE}$ & $\hat{\mathrm{u}}$ & SE \\
\hline Control mean & 2.08 & & 28.67 & & 178.21 & \\
\hline $\mathrm{I}-\mathrm{C}$ & -0.007 & 0.04 & $-1.58^{*}$ & 0.61 & 2.86 & 3.42 \\
\hline$R: P-F 1$ & $0.26^{*}$ & 0.11 & $-2.74^{*}$ & 1.23 & $\mathrm{NS}^{\mathrm{d}}$ & \\
\hline$(\mathrm{I}-\mathrm{C})_{\mathrm{P}}$ & $-0.12^{* *}$ & 0.03 & -0.21 & 0.43 & & \\
\hline$(\mathrm{I}-\mathrm{C})_{\mathrm{F} 1}$ & 0.08 & 0.05 & $-1.48^{*}$ & 0.57 & & \\
\hline $\mathrm{F} 1-\mathrm{P}$ & $-0.34 * *$ & 0.04 & $4.29 * *$ & 0.47 & $-31.19 * *$ & 2.45 \\
\hline
\end{tabular}

Table 6. Contrasts among means for growth traits of individually penned pigs

\begin{tabular}{|c|c|c|c|c|c|c|c|c|}
\hline \multirow[b]{2}{*}{ Contrast $^{\mathrm{a}}$} & \multicolumn{2}{|c|}{$\mathrm{ADFI}, \mathrm{kg}^{\mathrm{b}}$} & \multicolumn{2}{|c|}{$\mathrm{ADG}, \mathrm{kg}$} & \multicolumn{2}{|c|}{$\mathrm{G}: \mathrm{F}$} & \multicolumn{2}{|c|}{ Days to $113 \mathrm{~kg}$} \\
\hline & $\hat{\mathrm{u}}$ & $\mathrm{SE}$ & $\hat{\mathrm{u}}$ & $\mathrm{SE}$ & $\hat{\mathrm{u}}$ & $\mathrm{SE}$ & $\hat{\mathrm{u}}$ & $\mathrm{SE}$ \\
\hline Line $\mathrm{C}$ mean & 2.36 & & 0.68 & & 0.29 & & 199.53 & \\
\hline $\mathrm{I}-\mathrm{C}$ & 0.17 & 0.09 & 0.04 & 0.03 & -0.006 & 0.01 & -4.40 & 5.25 \\
\hline$R: P-F 1_{L}$ & $\mathrm{NS}^{\mathrm{c}}$ & & NS & & NS & & $-17.98^{*}$ & 8.85 \\
\hline$R: P-T$ & NS & & NS & & NS & & NS & \\
\hline $\mathrm{R}: \mathrm{T}-\mathrm{F} 1_{\mathrm{L}}$ & NS & & NS & & NS & & NS & \\
\hline $\mathrm{R}: \mathrm{T}-\mathrm{Fl}_{\mathrm{T}}$ & NS & & NS & & NS & & NS & \\
\hline$(\mathrm{I}-\mathrm{C})_{\mathrm{P}}$ & & & & & & & 4.58 & 4.00 \\
\hline$(\mathrm{I}-\mathrm{C})_{\mathrm{F} 1 \mathrm{~L}}$ & & & & & & & -6.70 & 3.95 \\
\hline $\mathrm{F} 1_{\mathrm{L}}-\mathrm{P}$ & $0.26^{* *}$ & 0.05 & $0.19 * *$ & 0.02 & $0.045^{* *}$ & 0.006 & $-27.65^{* *}$ & 2.81 \\
\hline $\mathrm{T}-\mathrm{F} 1_{\mathrm{L}}$ & -0.06 & 0.05 & 0.01 & 0.02 & $0.013^{*}$ & 0.006 & -3.33 & 2.82 \\
\hline $\mathrm{T}-\mathrm{F} 1_{\mathrm{T}}$ & 0.02 & 0.06 & 0.03 & 0.02 & 0.008 & 0.006 & -2.87 & 3.22 \\
\hline
\end{tabular}

Table 7. Contrasts among means for carcass traits at $113 \mathrm{~kg}$ live weight of individually penned pigs

\begin{tabular}{|c|c|c|c|c|c|c|c|c|c|c|}
\hline \multirow[b]{2}{*}{ Contrast $^{\mathrm{a}}$} & \multicolumn{2}{|c|}{$\mathrm{BF}, \mathrm{cm}^{\mathrm{b}}$} & \multicolumn{2}{|c|}{$\mathrm{LM}$ area, $\mathrm{cm}^{2 \mathrm{c}}$} & \multicolumn{2}{|c|}{ LEAN\% ${ }^{\mathrm{d}}$} & \multicolumn{2}{|c|}{$\mathrm{pH}^{\mathrm{e}}$} & \multicolumn{2}{|c|}{$L^{* f}$} \\
\hline & $\hat{\mathrm{u}}$ & $\mathrm{SE}$ & $\hat{\mathrm{u}}$ & $\mathrm{SE}$ & $\hat{\mathrm{u}}$ & $\mathrm{SE}$ & $\hat{\mathrm{u}}$ & $\mathrm{SE}$ & $\hat{\mathrm{u}}$ & $\mathrm{SE}$ \\
\hline Line $\mathrm{C}$ mean & 2.81 & & 33.61 & & 41.42 & & 5.66 & & 44.93 & \\
\hline $\mathrm{I}-\mathrm{C}$ & 0.25 & 0.16 & -1.00 & 1.66 & -0.40 & 1.56 & -0.04 & 0.08 & 1.01 & 2.52 \\
\hline$R: P-F 1_{L}$ & $\mathrm{NS}^{\mathrm{g}}$ & & NS & & NS & & NS & & NS & \\
\hline $\mathrm{R}: \mathrm{P}-\mathrm{T}$ & NS & & NS & & NS & & NS & & NS & \\
\hline $\mathrm{R}: \mathrm{T}-\mathrm{F} 1_{\mathrm{L}}$ & NS & & NS & & NS & & NS & & NS & \\
\hline $\mathrm{R}: \mathrm{T}-\mathrm{Fl}_{\mathrm{T}}$ & NS & & NS & & NS & & NS & & NS & \\
\hline $\mathrm{F} 1_{\mathrm{L}}-\mathrm{P}$ & $-0.82 * *$ & 0.10 & $5.22^{* * *}$ & 0.99 & $5.52 * *$ & 0.96 & -0.09 & 0.05 & $4.54^{* *}$ & 1.49 \\
\hline $\mathrm{T}-\mathrm{F} 1_{\mathrm{L}}$ & -0.15 & 0.09 & 1.04 & 0.89 & 1.39 & 0.83 & -0.01 & 0.04 & 1.45 & 1.36 \\
\hline $\mathrm{T}-\mathrm{F} 1_{\mathrm{T}}$ & -0.06 & 0.10 & $2.96 * *$ & 1.01 & 0.08 & 0.96 & -0.03 & 0.05 & 1.04 & 1.56 \\
\hline
\end{tabular}

$* * P<0.01$.

${ }^{\text {a See Table }} 4$ for definition of contrasts.

${ }^{\mathrm{b}} \mathrm{BF}=$ backfat at $113 \mathrm{~kg}$.

${ }^{\mathrm{c}} \mathrm{LM}$ area at $113 \mathrm{~kg}$.

${ }^{\mathrm{d}}$ LEAN\% = percentage of carcass lean measured with total body electrical conductivity (TOBEC).

${ }^{\mathrm{e}} \mathrm{pH}=\mathrm{LM} \mathrm{pH}$ at $24 \mathrm{~h}$ after slaughter.

${ }^{\mathrm{f}} \mathrm{L}^{*}=\mathrm{LM}$ Minolta $\mathrm{L}^{*}$ color score.

${ }^{\mathrm{g}} \mathrm{NS}=$ not significant. 
It was only for LM area in group-fed gilts that a significant correlated response $\left(-1.58 \pm 0.61 \mathrm{~cm}^{2}\right)$ was detected. The response was in the same direction and similar in magnitude in the barrows and gilts that were individually fed $\left(-1.00 \pm 1.66 \mathrm{~cm}^{2}\right)$. The average of these estimates $\left(-1.28 \pm 0.88 \mathrm{~cm}^{2}\right)$ provides some evidence of a reduction in LM area from long-term selection for litter size and its component traits. However, statistically detectable responses did not occur for any other trait, including percentage of carcass lean, a trait positively related with LM area.

Several researchers have previously estimated genetic correlations of litter size with growth and carcass traits. Most of these estimates are from covariance analyses or from correlated responses in litter size to selection for either growth or carcass traits. They often have large standard errors and in some cases are contradictory. For example, Young et al. (1977) found moderate to high genetic correlations between ovulation rate and BW at several ages, and with rate of growth $\left(r_{g}>0.41\right)$, indicating that selection for ovulation rate is expected to result in a correlated increase in growth rate. Genetic correlations were estimated from sire components of covariance, which were negative for embryonic survival and litter size and thus prevented estimating correlations of these traits with growth traits. Bereskin (1984) estimated these relationships from 732 pairs of daughter-dam records for both growth and reproductive traits. Genetic correlations of the total number of pigs born per litter with $\mathrm{ADG}$ and days to $90.7 \mathrm{~kg}$ were outside the parameter space $(-2.14 \pm 9.6$ and $4.05 \pm$ 18.0, respectively). Genetic correlations with $\mathrm{BF}$ and LM area were moderate to large, but also had very large standard errors $(-0.54 \pm 2.5$ and $1.01 \pm 4.6$, respectively).

Estimates of responses in litter size from selection for lean growth rate have been estimated in several studies. Generally, responses were small and not significantly different from zero (Fredeen and Mikami, 1986; Cleveland et al., 1988; Kerr and Cameron, 1995). However, Kerr and Cameron (1995) found that selection for certain aspects of lean growth rate that reduced daily feed intake, such as direct selection for reduced feed intake and selection for high lean food conversion ratio, caused a correlated reduction in litter size at birth. These experiments indicate that selection practices that emphasize increased lean growth rate with ad libitum feeding should not cause correlated responses in litter size.

Few other long-term selection experiments for litter size have been conducted; thus, there are few direct results in the literature to compare with results reported herein. In another study reported by Ruíz-Flores and Johnson (2001), eight generations of two-stage selection for ovulation rate and litter size were practiced in each of two lines that were derived at Generation 8 from the Index and Control lines of this project. Averaged across lines, they reported genetic correlations of -0.09 and 0.24 for BF at $95 \mathrm{~kg}$ and BW at $178 \mathrm{~d}$, respectively, with ovulation rate. Genetic correlations of the same growth traits with total number born per litter were 0.44 and 0.22 , respectively. Positive genetic trends in $\mathrm{BF}$ occurred in the two-stage selection line that originated from Line $\mathrm{C}(0.30 \pm 0.07 \mathrm{~mm}$ per generation), but not in the line that originated from Line I $(0.10 \pm 0.07 \mathrm{~mm}$ per generation). Genetic trends in BW were positive in both lines, being $0.011 \pm 0.011 \mathrm{~kg}$ in the line that originated from Line I and $0.006 \pm 0.002$ $\mathrm{kg}$ in the line derived from Line $\mathrm{C}$. In another line that was derived from the same control line used in the project reported herein, and in which nine generations of direct selection for litter size were practiced, Holl and Robison (2003) found that correlated responses in $\mathrm{BF}$ and days to $104 \mathrm{~kg}$ were not significant.

In another study, Estany et al. (2002a) estimated correlated responses in growth traits in a line selected one generation for increased litter size in which the response was estimated to be 0.46 live pigs per litter. The select and control lines had significantly different patterns of growth and fat deposition from 75 to $162 \mathrm{~d}$ of age. Body weight of select line pigs was greater to approximately $135 \mathrm{~d}$, but the lines did not differ at the end of the test. Backfat at $165 \mathrm{~d}$ of age was approximately $1.3 \mathrm{~mm}$ greater $(P<0.01)$ in select line pigs. Lines did not differ in feed intake or feed efficiency during the total test period. Responses in carcass backfat were similar to those in live animals estimated with ultrasound (Estany et al., 2002b). No other important changes in carcass measurements or meat quality traits occurred.

A second objective of our experiment was to determine whether correlated selection responses were similar in pure line and crossbred pigs. An interaction of line differences with genetic group occurred for both $\mathrm{BF}$ and LM area of group-fed gilts, but not in barrows and gilts fed individually. A significant interaction for days to $113 \mathrm{~kg}$ in barrows and gilts fed individually also was detected, but no interaction for days to 88.2 $\mathrm{kg}$ in group-fed gilts occurred. These interactions imply different expression of genes in crossbred pigs than in pure line pigs due to epistasis. However, there are other possible explanations. The inbreeding coefficient in Line I was approximately $7.5 \%$ greater than in Line $\mathrm{C}$, which could have contributed to the interaction as greater inbreeding depression and greater recovery from heterosis were then expected in Line I. The observed results for BF in group-fed gilts and days to 113 $\mathrm{kg}$ in barrows and gilts fed individually were in this direction. Pure line I group-fed gilts had less BF than $\mathrm{C}$ gilts, whereas the difference was positive in $\mathrm{F}_{1}$ gilts. Pure line I barrows and gilts took more days to reach $113 \mathrm{~kg}$ than $\mathrm{C}$ pigs, but the difference was just the opposite in $F_{1}$ pigs. The same $L$ sires were used to produce the $\mathrm{F}_{1} \mathrm{~L} \times \mathrm{I}$ and $\mathrm{L} \times \mathrm{C}$ pigs. Therefore, sire effects were not expected to contribute to differences between $\mathrm{L} \times \mathrm{I}$ and $\mathrm{L} \times \mathrm{C}$ pigs. However, sampling may have resulted in genetic differences between dams and sires within Lines I and C, which also could cause an 
interaction. It is not possible to investigate these possibilities, but because the same interactions were not observed in group-fed pigs and the pigs fed individually, sampling is the most plausible explanation.

In a national maternal line evaluation (NPPC, 2000), an $\mathrm{F}_{1}$ female of Line $\mathrm{I}$ and a commercial maternal line had 30 to $50 \%$ greater lifetime reproductive performance than five other commercially available $F_{1}$ females. As a result, Line I was released to the industry and a third aim of this research was to estimate the improvements that can be realized from crossing Line I with an improved commercial line. The advantages of crossbred pigs over pure line pigs were substantial for all traits. Three-way cross pigs by $F_{1}$ dams and terminal line sires reached market weight approximately $31 \mathrm{~d}$ sooner than pure line pigs and had approximately 7\% more carcass lean. Most of this improvement came from the first cross as three-way crosses were only $3.33 \pm 2.82 \mathrm{~d}$ younger with $1.39 \pm 0.83 \%$ more carcass lean at $113 \mathrm{~kg}$ than did $\mathrm{F} 1_{\mathrm{L}}$ cross pigs. Many workers have previously shown heterosis for growth rate to be between 7 to $10 \%$, and heterosis for carcass traits being less than 1 to $3 \%$ (Johnson, 1981). Therefore, most of the large advantages for the $\mathrm{F}_{1}$ pigs can be attributed to effects of the $\mathrm{L}$ and $\mathrm{T}$ sires.

\section{Implications}

In this experiment, correlated responses in growth and carcass traits after 19 generations of selection for ovulation rate, embryonic survival, and litter size were very small. Significant correlated responses have occurred in other experiments in which much less selection was applied than in the Index line of this study, although observed responses in these studies have been relatively small. This finding indicates that genetic correlations of litter size, ovulation rate, and embryonic survival with growth and carcass traits are very small and close to zero. Selection for litter size is expected to have very little effect on growth and carcass traits. For practical purposes, litter size can be analyzed independently from growth and carcass traits in genetic evalua- tion programs. Crossbreeding is an effective breeding strategy that complements prolificacy with improved growth and carcass merit in pig production systems.

\section{Literature Cited}

Bereskin, B. 1984. Genetic correlations of pig performance and sow productivity traits. J. Anim. Sci. 59:1477-1487.

Cleveland, E. R., R. K. Johnson, and P. J. Cunningham. 1988. Correlated responses of carcass and reproductive traits to selection for rate of Lean growth in swine. J. Anim. Sci. 66:1371-1377.

Estany, J., D. Villalba, J. Tibau, J. Soler, D. Babot, and J. L. Noguera. 2002a. Correlated response to selection for litter size in pigs: I. Growth, fat deposition, and feeding behavior traits. J. Anim. Sci. 80:2556-2565.

Estany, J., D. Villalba, M. Tor, D. Cubiló, and J. L. Noguera. 2002b. Correlated response to selection for litter size in pigs: II. Carcass, meat, and fat quality traits. J. Anim. Sci. 80:2566-2573.

Fredeen, H. T., and H. Mikami. 1986. Mass selection in a pig population: correlated responses in reproductive performance. J. Anim. Sci. 62:1523-1532.

Holl, J. W., and O. W. Robison. 2003. Results from nine generations of selection for increased litter size in swine. J. Anim. Sci. 81:624-629.

Johnson, R. K. 1981. Crossbreeding in swine: Experimental results. J. Anim. Sci. 52:906-923.

Johnson, R. K., M. K. Nielsen, and D. S. Casey. 1999. Responses in ovulation rate, embryonal survival, and litter traits in swine to 14 generations of selection to increase litter size. J. Anim. Sci. 77:541-557.

Kerr, J. C., and N. D. Cameron. 1995. Reproductive performance of pigs selected for components of efficient Lean growth. Animal Science. 60:281-290.

NSIF. 1991. Swine Genetics Handbook. National Swine Improvement Federation. Available: http://persephone.agcom.purdue.edu/AgCom/Pubs/NSIF/NSIF-5/NSIF-FS6.html. Accessed March 14, 2000.

NPPC. 2000. Maternal line national genetic evaluation program results. Natl. Pork Prod. Council Pub. No. 04466. Des Moines, IA.

Petry, D. B. and R. K. Johnson. 2004. Responses to 19 generations of litter size selection in the NE Index line. I. Reproductive responses estimated in pure line and crossbred litters. J. Anim. Sci. (In press).

Ruíz-Flores, A., and R. K. Johnson. 2001. Direct and correlated responses to two-stage selection for ovulation rate and number of fully formed pigs at birth in swine. J. Anim. Sci. 79:2286-2297.

Young, L. D., R. K. Johnson, and I. T. Omtvedt. 1977. An analysis of the dependency structure between a gilt's prebreeding and reproductive traits. I. Phenotypic and genetic correlations. J. Anim. Sci. 44:557-564. 